\section{Apparent Turnover Rate of Diaphragm Proteins in Rats}

\section{Toshihide Kasahara and Masao Kametaka \\ Department of Agricultural Chemistry, Faculty of Agriculture, The University of Tokyo, Tokyo}

Received December 10, 1974

In spite of the frequent usage of the diaphragm as a suitable muscle slice in experiments in vitro, knowledge concerning protein metabolism of the diaphragm in vivo is not so plentiful. In the present study, the protein loss from the diaphragm in rats during the early stages of dietary protein deficiency and apparent turnover rate of mixed diaphragm proteins after a single injection of L-leucine-4,5- ${ }^{3} \mathrm{H}$ were examined in comparison with those of the liver, skeletal muscle (hind leg) and heart.

Wistar male rats weighing $140 \sim 165 \mathrm{~g}$ were prefed for 5 days a control diet containing $65 \%$ corn starch, $20 \%$ casein, $5 \%$ soybean oil, $5 \%$ cellulose powder, $4 \%$ salt mixture, ${ }^{*} 0.85 \%$ vitamin mixture* and $0.15 \%$ choline chloride, followed by receiving intraperitoneally $50 \mu \mathrm{Ci}$ of L-leucine- $4,5-{ }^{3} \mathrm{H}$ per $100 \mathrm{~g}$ of body weight. Six hours after the injection of the labeled amino acid, three rats were killed and the remaining were divided into 2 groups of 6 animals each. One group was fed the control diet and the other the protein-free diet which was prepared by replacing casein in the control diet with corn starch. Food and water were given ad libitum. Three rats from each group were killed on the 2nd and 5th days after the injection of the labeled amino acid respectively. The liver, skeletal muscle ( $M$. gastrocnemius, plantaris and soleus), heart and diaphragm were weighed and homogenized in $5 \%(w / v)$ trichloroacetic acid (TCA) in a glass PotterElvehjem homogenizer. The homogenate was centrifuged and the TCA-insoluble fraction was washed twice with $5 \% \mathrm{TCA}$, heated in $5 \% \mathrm{TCA}$ at $95^{\circ} \mathrm{C}$ for $15 \mathrm{~min}$ to extract nucleic acids and then washed once with ethanol-ether $(1: 1)$ and once with ether alone. The residue protein was dissolved in $1 \mathrm{~N} \mathrm{NaOH}$ and an aliquot was taken for determination of protein nitrogen by the Kjeldahl method. For measurement of radioactivity, $0.5 \mathrm{ml}$ of protein sample was transferred to a counting vial, mixed with $10 \mathrm{ml}$ of toluenemethylcellosolve scintillation solution and then counted

* A. E. Harper, J. Nutr., 68, 408 (1959). Obtained from Tanabe Amino Acid Research Foundation, Osaka, Japan. Vitamins $A, D$, and $E$ were added according to the same literature.

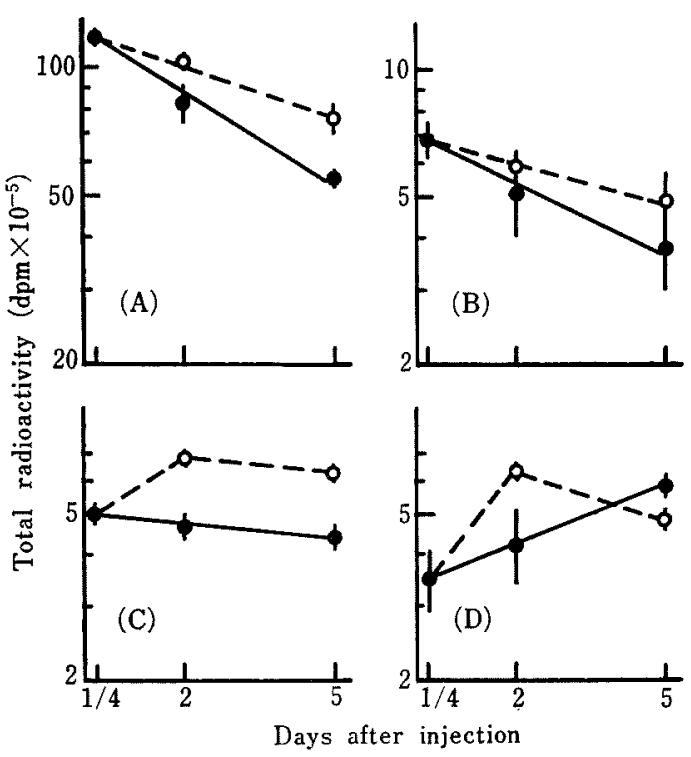

FIG. 1. Total Radioactivity in Proteins of Liver (A), Diaphragm (B), Heart (C) and Skeletal Muscle (D) in Rats Receiving $50 \mu \mathrm{Ci}$ of L-Leucine- $4,5-{ }^{8} \mathrm{H}$ per $100 \mathrm{~g}$ of Body Weight, Followed by Feeding Control (-) or Protein-free (O--O) Diet.

The total radioactivity is plotted logarithmically against time after injection. Each point is the mean of the results from 3 rats. The vertical bars indicate standard errors.

in a scintillation spectrometer (Horiba LS 500). All counts were corrected by means of counting efficiency estimated for each sample using an external standard and the results were expressed as the total radioactivity (dpm) in the whole tissue proteins. In preliminary experiments, we observed by paperchromato-scanning techniques that the radioactivity in the liver and diaphragm proteins was almost completely recovered as leucine after the injection of $L$ leucine-4,5- ${ }^{3} \mathrm{H}$.

The changes in body weight and the protein content of tissues are shown in Table I. The results obtained with regard to the protein loss from the liver and skeletal muscle during the early stages of protein deficiency were generally consistent with those obtained by other workers. ${ }^{11}$ The liver lost about 25 and $34 \%$ of the initial protein and skeletal muscle lost about 2 and $8 \%$ after 2 and 5 days respectively. On the other hand, the heart did not begin to lose its protein until the 2 nd day after the diet was changed to the protein-free diet and the protein content decreased by only $3 \%$ of the initial value after 5 days. This suggests that the heart responds more slowly to the dietary protein deficiency. Allison et al., however, observed a marked reduction in the protein/DNA ratio in the heart of rats during 
Table I. Changes in Body Weight and Protein Content of Tissues during Experimental Periods

\begin{tabular}{|c|c|c|c|c|c|c|}
\hline \multirow{2}{*}{ Diets } & \multirow{2}{*}{$\begin{array}{c}\text { Days on } \\
\text { diet }\end{array}$} & \multirow{2}{*}{$\begin{array}{l}\text { Body } \\
\text { weight } \\
\text { (g) }\end{array}$} & \multicolumn{4}{|c|}{ Protein content $^{a)}(\mathrm{N} \times 6.25)$} \\
\hline & & & Liver & Diaphragm & Skeletal M. & Heart \\
\hline \multirow{3}{*}{ Control } & 0 & 172.5 & $616 \pm 18^{b 1}$ & $40.4 \pm 0.5$ & $84.8 \pm 2.3$ & $60.3 \pm 4.0$ \\
\hline & 2 & 181.4 & $628 \pm 16$ & $43.3 \pm 2.1$ & $87.6 \pm 3.7$ & $62.1 \pm 4.3$ \\
\hline & 5 & 206.3 & $750 \pm 17$ & $44.2 \pm 1.1$ & $105.2 \pm 3.3$ & $67.1 \pm 2.0$ \\
\hline \multirow[t]{2}{*}{ Protein-free } & 2 & 168.0 & $461 \pm 10^{2 *}$ & $37.0 \pm 1.6$ & $82.9 \pm 2.6$ & $63.5 \pm 0.9$ \\
\hline & 5 & 161.5 & $407 \pm 10^{2 *}$ & $35.5 \pm 1.6^{1 *}$ & $78.0 \pm 1.3$ & $58.6 \pm 0.5$ \\
\hline
\end{tabular}

a) Each value is the mean of the results from 3 rats and expressed as mg protein / tissue / $100 \mathrm{~g}$ of the initial body weight.

b) Mean \pm SEM.

* Differed significantly $\left({ }^{*} p<0.05 ;{ }^{2 *} p<0.01\right.$ ) from the initial value.

the initial stages of protein deficiency. ${ }^{2)}$ The protein loss from the diaphragm was about 8 and $12 \%$ of the initial protein after 2 and 5 days respectively and as a result the diaphragm lost its protein more rapidly than skeletal muscle and the heart.

The changes in the total radioactivity in the tissue proteins after the injection of $\mathrm{L}-\mathrm{leucine}-4,5-{ }^{3} \mathrm{H}$ are shown in Fig. 1. Apparent half-lives of the liver, diaphragm and heart proteins in control rats were calculated from the slopes as 4.0, 5.2 and more than 13.0 days respectively. Since these values seem to be overestimated because of the reutilization of the labeled amino acid liberated from proteins by degradation, ${ }^{3)}$ it is likely that the actual half-lives are less than the values obtained. In fact, the half-life of mixed liver proteins was estimated as 3.3 days using guanidino- $\mathrm{L}$-arginine- ${ }^{14} \mathrm{C}^{31}$ and as 1.55 days using sodium carbonate- ${ }^{14} \mathrm{C} .{ }^{4}$ ) On the other hand, the radioactivity in skeletal muscle proteins in control rats continued to increase throughout the duration of the experiments. This suggests that skeletal muscle proteins have a slower turnover rate. Recently, Millward showed that the half-life of mixed skeletal muscle ( $M$. gastrocnemius) proteins was estimated as 10.5 days using sodium carbonate- ${ }^{14} \mathrm{C}$ which was reutilized to a very small extent. ${ }^{5}$ From these results it is certain that the diaphragm proteins have a more rapid turnover rate than the heart and skeletal muscle proteins.

Peterson et al. stated that rat diaphragm was not necessarily typical of skeletal muscle with respect to oxidative metabolism. ${ }^{6}$ With respect to protein metabolism in vivo also, the diaphragm probably differs from skeletal muscle. Although we must not jump to any careless conclusions about muscle protein metabolism from the results obtained in the investigations using the diaphragm in vitro, the effectiveness of the diaphragm as a muscle slice is not necessarily changed.

\section{REFERENCES}

1) H. N. Munro, "Mammalian Protein Metabolism," Vol. I, ed. by H. N. Munro and J. B. Allison, Academic Press, New York, 1964, p. 381.

2) J. B. Allison, R. W. Wannemacher and W. L. Banks, Federation Proc., 22, 1126 (1963).

3) R.T. Schimke, "Mammalian Protein Metabolism," Vol. IV, ed. by H. N. Munro, Academic Press, New York, 1970, p. 177.

4) D. J. Millward, Clin. Sci., 39, 591 (1970).

5) D. J. Millward, ibid., 39, 577 (1970).

6) R. D. Peterson, C. H. Beatty and R. M. Bocek, Amer. J. Physiol., 200, 182 (1961); idem, Endocrinology, 72, 71 (1963). 